\title{
Sustainable irrigation in areas with an arid and semi-arid climate in the province of Alicante
}

\author{
C. J. Sánchez-Rubio \\ Institute of Water and Environmental Science, \\ University of Alicante, Spain
}

\begin{abstract}
The lack of water in sufficient quantity and quality is the main cause of the reduction of the irrigated area in the region studied in the province of Alicante. The irrigated area has incorporated the most advanced agricultural techniques (greenhouses) and irrigation systems for greater efficiency in water use (localized) obtaining economic, social and environmental sustainability. This vanguard agriculture is sustainable, profitable, exports on both a national scale and to the European Union, generates employment, enjoys a favourable income situation and has a set of objective conditions and advantages confirming its importance in the recent process of agrarian economy. This new agricultural irrigation has been the engine of economic and social development but it is not a final solution to solve the problems of regional imbalance.

Keywords: water scarcity, irrigation, vanguard agriculture, export, profitable and sustainable.
\end{abstract}

\section{Objectives}

This work aims to study and analyse the economic, social and environmental aspects of sustainable irrigated agriculture in areas with an arid and semi-arid climate in the province of Alicante to establish a diagnosis of the deficits, advantages and potential. Also, to address the lack of guarantee of water for agricultural use through better management and optimization of this resource: saving, reuse of reclaimed flows, desalination, and even new posts alien to recover the comparative advantages of sustainable vanguard agriculture (vegetables, citrus fruits, flowers and ornamental plants) in the domestic market and the European Union. The region studied includes both the areas with an arid 
climate (Bajo-Segura and Bajo-Vinalopó) and with a semi-arid climate (AltoVinalopó, Medio-Vinalopó, Campo de Alicante and La Marina Baja).

\section{The traditional model of productive agricultural and the environmental problems generated}

\subsection{A physical environment with risks and opportunities for agricultural use of land}

The biggest limiting factor of agricultural irrigation is the non-availability of water in sufficient quantity and quality in the region studied (Fig. 1). Irrigation means multiplying profitability in the area of upland between 10 and 15 times. An Alicante farmer, skilled, dynamic and favoured by their income situation is

Tipología climática de las comarcas de Alicante

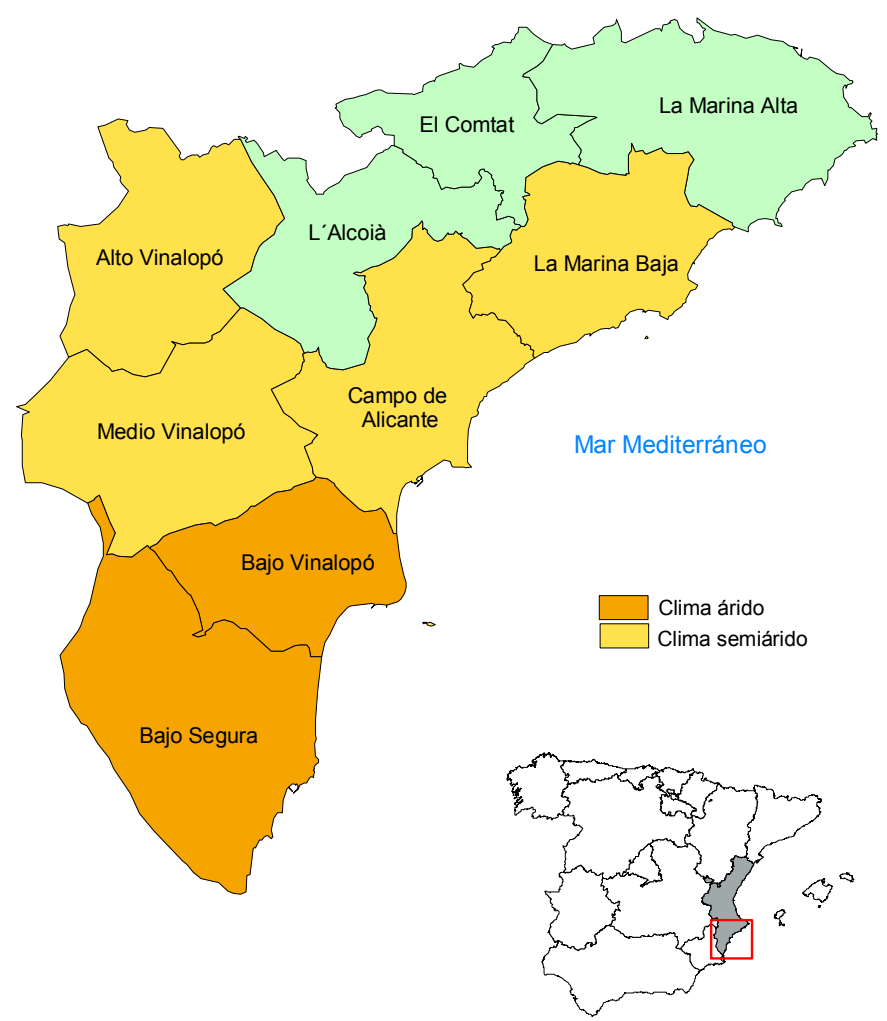

clima arido $=$ dry climate, clima semiarido $=$ semi-dry climate

Figure 1: Type climate of the province of Alicante. 
synonymous with exporter but influenced by endogenous processes (erratic and little rainfall) and exogenous Common Agricultural Policy (CAP), World Trade rganization (WTO), Framework Directive of Water (FDW), the non-agricultural water demands and technology). The ability to regulate water for irrigation involves converting a strangulation risk into a large productive strength that does not allow the cultivation of upland dependent on the timing and amount of precipitation.

The control the of surface water flow, retaining it through dams and storing it in reservoirs or diverting it through channels enjoys a long tradition in the region of Alicante. The existence of irrigation farming goes back to the Muslim era. Characterized by the exclusive use of the resources of the Segura river surface to transform unproductive soil in areas of considerable wealth (Bajo-Segura), is growing with the construction of reservoirs in Tibi (1579) to supply the Huerta de Alicante and in Elche the Vinalopó area in the following century. The search for new water resources led to the construction of important waterworks throughout the $20^{\text {th }}$ century such as: the Canal de la Huerta of Alicante, which was opened in 1909, which supplies water from artesian wells in Alto Vinalopó (Villena) and the Compañia de Riegos de Levante (The Levante Irrigation Company) by granting flow surplus from the Segura river in 1918, whose infrastructure ranges from the Bajo Segura to the Campo de Alicante.

The processes described are always related to the use of agricultural water, attempting to promote the economic development of the area through the continued expansion of the irrigated area.

The use of surface water was instigated by the Government to regulate the use of a particular flow of public water is a paradigmatic example in the Plan for the use of the River Segura, according to the Bill of $25^{\text {th }}$ April 1953, which assesses the future availability, allocation to the various irrigated areas and the land subject of enlargement. The physical and ecological potential, the high production and the income generated (6-7 six times higher, when the average in Spain is only four times higher) encouraged the exploitation of groundwater between 1960-1980 as a private initiative, as an alternative to ensure the availability of water for production of the irrigated area. This is the source of the new irrigation agriculture which incorporates new technologies (localized irrigation), to reduce water consumption per unit area, that are intensive (greenhouses) and productive and preferably located with preferential in the coastal areas. This new agriculture is based on small technified production units, flamboyant crops and preferential sales to foreign markets. The extraction of water in the region studied led to an alarming decline in the aquifers which made it necessary to transfer water from the headwaters of the River Tajo to the River Segura. The scarcity of water resources in relation to the growing demand obliges the State to take certain restrictive measures in determined areas which are also applicable in others (Bajo-Segura, Bajo Vinalopó and Campo de Alicante). Irrigated agriculture, industry, tourism and leisure with the corresponding urban consumption have increased pressure on existing water resources. The greatest increase in the need for water occurs in the region studied, making it necessary to transfer surplus flow from the headwaters of the 
River Tajo, based on final production criteria and economic and social efficiency.

The use of surface water was instigated by the Government to regulate the use of a particular flow of public water is a paradigmatic example in the Plan for the use of the River Segura, according to the Bill of $25^{\text {th }}$ April 1953, which assesses the future availability, allocation to the various irrigated areas and the land subject of enlargement. The physical and ecological potential, the high production and the income generated (6-7 six times higher, when the average in Spain is only four times higher) encouraged the exploitation of groundwater between 1960-1980 as a private initiative, as an alternative to ensure the availability of water for production of the irrigated area. This is the source of the new irrigation agriculture which incorporates new technologies (localized irrigation), to reduce water consumption per unit area, that are intensive (greenhouses) and productive and preferably located with preferential in the coastal areas. This new agriculture is based on small technified production units, flamboyant crops and preferential sales to foreign markets.

The extraction of water in the region studied led to an alarming decline in the aquifers which made it necessary to transfer water from the headwaters of the River Tajo to the River Segura. The scarcity of water resources in relation to the growing demand obliges the State to take certain restrictive measures in determined areas which are also applicable in others (Bajo-Segura, Bajo Vinalopó and Campo de Alicante). Irrigated agriculture, industry, tourism and leisure with the corresponding urban consumption have increased pressure on existing water resources. The greatest increase in the need for water occurs in the region studied, making it necessary to transfer surplus flow from the headwaters of the River Tajo, based on final production criteria and economic and social efficiency.

Act $2 / 1980$ of $16^{\text {th }}$ October on "Regulation of the economic system of exploitation of the Tajo-Segura aqueduct", in its first additional provision, assigns a volume of $127.8 \mathrm{hm}^{3} /$ year for agricultural use in the Lower Segura, Lower Vinalopó and Campo de Alicante regions. These flows of water are the reason for the expansion of the irrigation area to a maximum of 123,936 ha. In $1986(100 \%)$ which was reduced to 97,550 ha. by the year $2006(78.7 \%)$ due to the insecurity and uncertainty of receiving the volume of water allocated because of the continuing drought periods at the head of the Tajo river in the Segura basin (Table 1). Therefore, the objective and strategies in the irrigated area is estimated at consolidation by guaranteeing supply (transfer, sewage and treated water, desalination plants, surveys and recharging of aquifers), and modernization (savings, localized irrigation, improved management efficiency). This is the best way to have sufficient allocations, high efficiency and environmental improvement. 


\subsection{The development model of productive agriculture: economic benefits and environmental impact}

The Spanish policy in rural areas has been defined by two criteria: economic/political/social and productive. The first is aimed at increasing the returns to supply the growing food demand. The solution offered was the expansion of irrigated area to make it a vanguard, in the mid-fifties, agricultural modernization of the country. This productive agriculture is profitable, competitive and dynamic as a basic factor for the development of the rural world. One area favoured by bringing Spain into the former European Economic Community (EEC) that acquires major economic impact (for ease of marketing their products derived from citrus, vegetables, fruit etc.) and social (creates a lot more jobs than the same rain-fed surface and fixed population in rural areas). The irrigation of the new territorial unit aimed to increase production, productivity and be of a family character. Demand for these products has grown significantly as a result of demographic changes, the income level of the population and the new diet. The farmer's response has been the intensification of agricultural production through increased food and its variety. This process has been carried out by incorporating technological advances, chemicals (fertilizer) and mechanization. The farm owner decided on the idea that investing more would increase his earnings. He began dialectic mechanization (without reducing wage labour) - productivity-emigration. The traditional model of agriculture was therefore abandoned and capitalism began in the agricultural sector so the model of subsistence was done with and production began to be intensified to meet the demands of new products. This process resulted in the appearance in rural areas of new functional and socio-economic relationships which altered traditional ways. The modern agricultural sector is linked with extra-regional commercial channels as opposed to the old system of city-country relations.

The irrigated area in the region studied adapted its products (citrus, fruits and vegetables, ornamental plants, flowers etc.) to the market thus converting traditional agriculture into modern agriculture dependent on exports. Few Spanish agricultural areas have experienced a change so radical in their agriculture as in this geographical area, confirmed statistically by improving familiar agricultural structures, the introduction of new crops, intensive vegetable development, the proliferation of greenhouses, replacing traditional irrigation by localized or drip, increased productivity and income of farmers and harvesters-exporters and the employment generated which in the irrigated coastal ranges from 30 times to 50 times that of rain-fed areas. A more practical way to acknowledge the crucial role played by vanguard agriculture in economic growth and level of income, both for its own monetary value as the multiplier effect generated in other sectors of its economy. Model consolidated land use, from the 1960 's sixties in the territorial unit to capture $90 \%$ of irrigated area and contribute the same percentage in the final agricultural production. The intensification of modern vanguard agriculture has significantly improved productivity through high prices and guarantee of sales in the domestic and 
community markets. The increased profitability comes from the utilization of land through: tomatoes, peppers, artichokes, lettuce, flowers, ornamental plants, citrus and almond in irrigation, constantly threatened by the lack of guarantee of water availability. Therefore, operation of a capitalized and intensive family nature, of greenhouse crops localized irrigation, cooperatives, marketing, etc., is being debated so as to match the size to the most favourable crops in the market, the optimum use of water (greenhouses, drip), the use of soluble fertilizers, construction of a framework for closer planting and saving in manpower. This is to face the future and the surrounding uncertainty in an intelligent and pragmatic manner to resolve the problems of more productive, competitive and dynamic agriculture in the province.

This intensification of soil irrigation and the advantages mentioned have caused problems for the rural community such as depletion of water resources (by disproportion between the irrigated surface and constant periods of drought, over-exploitation of groundwater), soil erosion and contamination of agricultural environments. Problems generated for productive agriculture created by Sustainable Agriculture. In other words, the old concept of growth based on the use of ever increasing water flow, of energy and raw materials is unsustainable and should give way to a less intensive exploitation of natural resources.

\section{The territorial model of sustainable irrigation: risks and opportunities}

Sustainable development was introduced as an explicit objective of the European Union in the Single European Act of 1987. The treaty of Maastricht 1992 obliges members to integrate environmental matters into all Community policies. Thus, irrigation agriculture of the territorial unity of Alicante must adapt its traditional approach to a framework where the predominant factors are the reduction of unit costs, increased product quality, preservation and maintenance of natural resources and environmental integration. Present and future irrigation must be able to manage water resources, obtaining an agricultural product competitive in quality and price in an increasingly global marketplace through compatibility with the economic, social and environmental criteria. This new concept identifies a form of irrigation capable of remaining indefinitely (durable) fulfilling the basic functions of being economically viable, socially useful and environmentally sustainable.

Under this new approach, it is necessary to abandon the symbolic nature which irrigation has traditionally had as an engine of development. Sustainable agriculture has to compete with other uses of water. Also, the Common Agricultural Policy (CAP) must involve the development of irrigation and sustainable development in force since 1992. The result of the CAP in Spain is the consolidation of a dual agriculture: intensive and hardly competitive or nonsubsidized, as compared to extensive cultivation of uncompetitive products (cereals) which is almost entirely subsidized. That is to say, the most promising horticultural sector in the regions of Alicante is at a disadvantage compared with 
less economically viable crops. We must produce what sells, rather than trying to sell what has been produced.

Sustainable agriculture in Alicante is conditioned by the new policy of agricultural markets and limited water resources. As a result of such constraints, irrigation has to be redirected from the traditional model to the new model which is sustainable through the rational use of water and the efficiency of the utilization of the resource from the perspectives of production and the environment must be increased.

\subsection{Ensuring water availability as a requirement of sustainable irrigation}

Sustainable irrigated agriculture in the regions of Alicante aims to ensure the need of water for crops and achieve greater efficiency in its use. Renewable indigenous resources and those from other regions, subject to irregularities in rainfall (drought) are not able to secure agricultural production under irrigation. The need to make the use of land more competitive involves ensuring adequate flow to the existing irrigated areas, before expanding new areas of irrigation. This approach is essential in the province of Alicante where water management is a very difficult and complex problem that coincides with a growing demand for agriculture, industry and urban supply, particularly tourism (in expansion), with increasingly scarce surface and underground water resources and a few outside sources dependent on availability of the headwaters of the River Tajo. Irrigation is the single largest user of water in the areas studied. This consumes $75 \%$ of water and produces, referring to the territory climate, between 5 and $8 \%$ of the gross domestic product in the agricultural district that falls to $2 \%$ when the value refers to the whole provincial. This agricultural sector contributed $15 \%$ of the total value of exports in 2006. The economic importance of the value of exports of agricultural products improved significantly from1999 to 2006, increasing by $35 \%$, from an amount of 263 to 550 million Euros. An amount that should be much higher but that was affected by the impact of drought that plagued the province of Alicante and the headwaters of the River Tajo. This lack of assurance of water resources has prompted both the incorporation of technological improvements (drip irrigation) and the increased availability of flows through regeneration that produces better drinking water than simple debugging. The latter is a process that involves improvement in the environment and optimizes the management of water. These are new technologies that extend to the practice of desalination of brackish and marine water to make new resources available to the farmer because the current systems do not ensure efficiency, fairness (ensuring water quantity and quality of the less favoured farming population) and sustainability. By constructing new desalination plants to supply the Irrigators Communities (Comunidades de Regantes) $\left(40 \mathrm{hm}^{3} /\right.$ year in Torrevieja and $60 \mathrm{hm}^{3} /$ year, according to requirements in Guardamar de Segura and another 16 medium and small size plants) at a price of $0.30 €$ (double the current rate of the Tajo-Segura aqueduct) it is hoped that agricultural development will be enhanced. This is one way to subsidize productive and sustainable agriculture in the Mediterranean. Accordingly, it is necessary to overcome the shortage of water and its impact on economic development in 
vanguard agriculture by offering a guarantee of water availability. Economizing on water will permit the comparative and profitable advantages of the territorial unit of Alicante to be recovered. The rise in horticulture has more to do with the dialectic integration-production-export than with aspects relating to ownership of land or poor structure of farms. And it is that by controlling the technical processes of greenhouses and localized irrigation, that reduces costs by the induced effects arising from fertigation and saving on manpower) higher yields and quality are obtained that reflect the status of the agricultural land boom in Alicante. There is an offer of agricultural products which is concentrated in the months of winter-spring during which there is little production and a high demand exists in the countries of the European Union. There is the advantage of a favourable climate and timetable if the problems due to drought and the price received by the farmer are overcome. The benefit obtained by the most significant crops shows that vegetables, citrus and table grapes because of their economic social and environmental viability, can assume the utilization of reclaimed, desalinated water and even of the transfer from other territories (ability of payment).

\subsection{Impact of the international market for trade}

The irrigation of crops in greenhouses and outdoors in the region is one way of producing land compatible with the CAP and the globalization tendencies of agricultural free trade that the WTO is trying to establish. This aims at liberalizing world agricultural trade by for example eliminating aid for agricultural production. Both the high level of production technology and the quality of the products of the region studied territorial unit of analysis allow it to compete in world markets. A skilled workforce is available that can maintain and increase production with no problem in the future. Irrigated agriculture will remain profitable and competitive even when applying the real costs of water contemplated in the Water Framework Directive of the European Union. The modern exploitation of crops is primarily competitive with respect to with land use in the area to achieve annual returns that exceed the selling price of land for urban use.

Horticultural exports and their value have gradually increased from 1999 to 2006. There has been a $25 \%$ increase in value $398,400 €$ to 498,470 . Increased exports related to the demands of the emerging markets of the developing countries, especially in the Asia-Pacific axis. Exports which are concentrated in the period from October to June and represent $85 \%$ and then decrease during the summer months when weather conditions allow the access of products from other territories to the markets.

The productive strength indicates that agricultural activity should continue improving product quality, health conditions and provide for the expansion of consumption by improving the standard of living of all EU countries. It will also improve transportation and phytosanitary control to be able to penetrate the market in the USA and Japan. This is the priority objective of the Horticultural Cooperative Pilar de la Horadada (Surinver), which manages the sale of the California pepper variety in those countries. This is a modern design of 
agricultural exporting that demands a guarantee and quality of water to improve on the size of farms and degree of marketing in order to compete more profitably in the increasingly globalized market.

\section{Conclusions}

The only agriculture that is sustainable, economical, social and environmental is that requiring the assurance of the necessary irrigation and water quality. The region of study brings together a number of objective and beneficial conditions to maintain and enhance the role of agricultural production in both the EU and the globalized markets. Agriculture in the region studied must be an engine of regional development although this is not the final solution to solve the problems of territorial imbalance.

\section{References}

[1] Juárez, C. (1991). Planificación hidrológica y desarrollo económico: El trasvase Tajo-Segura. Instituto "Juan Gil-Albert, Alicante : $167 \mathrm{pp}$.

[2] Juárez, C. (2004). Asignación de recursos de agua para uso agrario y crecimiento económico en la comarca meridional agraria de Alicante. Estudios Agrosociales y Pesqueros, ${ }^{\circ}$ 202, pp. 135-166.

[3] Juárez, C.; Ponce, G.; Ramón, A.; Canales, G. "Las agriculturas alicantinas" en Estructura económica de la provincia de Alicante. pp. 147-171. Diputación de Alicante 1993.

[4] Rico, A. M. (2006). Políticas agrarias, eficiencia socioeconómica y retos de futuro en los regadíos intensivos. B. de la A. G. E no 41 pp. 113-149. 